\title{
INFLUENCE OF SEASONS AND PLANT PARTS ON THE ESSENTIAL OIL COMPOSITION OF THE ENDEMIC SPECIES ARISTOLOCHIA KRISAGATHRA SIVARAJAN AND PRADEEP
}

\author{
SOUMYA MURALI ${ }^{*}$, RASHMI T. R. ${ }^{\mathrm{a}}$, FRANCIS M. S. ${ }^{\mathrm{b}}$ \\ a,bDepartment of Botany, Centre for Post-Graduate Studies and Research, Sacred Heart College, Thevara, Cochin, Kerala, India \\ Email: soumya.apr26@gmail.com
}

Received: 10 Jun 2016 Revised and Accepted: 22 Jul 2016

\section{ABSTRACT}

Objective: Aristolochia krisagathra, a species endemic to the Western Ghats of India is found closely allied to two other species native to India, $A$. indica and $A$. tagala. The plant is medicinally useful and hence may harbor important phytochemical constituents. The phytochemical studies on this plant are less. Hence, the objective of the research was to analyse the oil composition of this endemic plant considering the seasons and plant parts.

Methods: The essential oil analyses of both the leaf and stem oil of the plant was carried out in three different periods, pre-monsoon, monsoon and post-monsoon to analyse the major compounds present and the effect of seasons on the oil composition. Oil extraction of the shade dried leaves and stem were done in a clevenger type apparatus. $4 \mathrm{~h}$ of hydro distillation was done and the oil samples were analyzed by Gas Chromatography-Mass Spectrometry (GC-MS).

Results: The stem oil yield was higher than leaves and the oil colour of the leaves and stem varied. The results showed the predominance of sesquiterpenes. Diterpenes were completely absent in the stem oil in all the three seasons but was present in leaf oil in small concentrations. The oil yield from stem was higher than leaves. The major compound in the leaf and stem oil varied. Major compound in the pre-monsoon and postmonsoon remained the same, copaene in the leaf and alloaromadendrene in the stem. The major compound in the monsoon period was deltacadinene in leaf and spathulenol in stem. Caryophyllene, the sesquiterpene hydrocarbon, was present in both the stem and leaf oil irrespective of the seasons studied.

Conclusion: The study showed that the plant parts and seasons are important factors affecting the oil composition. Hence while collecting medicinal plants and their oils for various bioactivities, these factors need to be considered.

Keywords: A. krisagathra, Seasonal variation, Essential oil

(C) 2016 The Authors. Published by Innovare Academic Sciences Pvt Ltd. This is an open access article under the CC BY license (http://creativecommons. org/licenses/by/4. 0/) DOI: http://dx.doi.org/10.22159/ijpps.2016v8i9.13411

\section{INTRODUCTION}

The genus Aristolochia commonly known as 'Dutchmans pipe' or 'Birthworts' consists of approximately 500 species, most found in tropical, subtropical and Mediterranean regions having only certain degree of diversity in areas with seasonal climate of the Northern hemisphere [1, 2]. A. krisagathra Sivarajan and Pradeep, is one among the medicinally important species of Aristolochia reported from India and is endemic to the southern part of Western Ghats in Kerala and Tamil Nadu [3]. Studies on this endemic plant are limited. The juice of leaves and rhizome of $A$. krisagathra is used along with other plants for snakebite by the Kani tribes [4]. The presence of aristolochic acid I in the plant was reported and was found the highest among the four Aristolochia species included in the study [5].

Essential oils are important because of their bioactivity as antimicrobial agents [6]. Moreover these are sometimes used for systematic studies. A productive application of essential oil components to scientific plant classification requires knowledge of the causes of variation qualitatively and quantitatively [7]. Though the essential oil composition of $A$. krisagathra has already been reported [8], the oil composition in different seasons has not been studied. Hence the study aims to focus on the influence of two factors, seasons and plant part on the oil composition.

\section{MATERIALS AND METHODS}

The source plant $A$. krisagathra was collected from Rosemala near Aryankavu ( $8^{\circ} 58^{\prime} 0^{\prime \prime} \mathrm{N} 77^{\circ} 8^{\prime} 35^{\prime \prime} \mathrm{E}$ ), Kollam district of Kerala, India in three different seasons-pre-monsoon (March-May), monsoon (JuneSeptember) and post-monsoon (October-February). The species was authenticated and voucher specimens (A. indica-SHC: 07, A. tagalaSHC: 08, A. ringens-SHC: 09, A. krisagathra-SHC: 10) deposited in the herbarium of Sacred Heart College, Thevara. The leaves and stem were separated, shade dried and powdered. $100 \mathrm{~g}$ each of powdered plant material of leaf and stem was hydrodistilled using a clevenger type apparatus. The time of distillation was $4 \mathrm{~h}$ and the distillate obtained was collected and stored in vials under refrigeration $\left(4^{\circ} \mathrm{C}\right)$ prior analysis.

The composition of the volatile constituents was established by GCMS analyses [9] using GC-6850 network GC system, Agilent technologies with column type HP5MS $30.0 \mathrm{~m} \times 250.00 \mu \mathrm{m}$, film thickness $0.25 \mu \mathrm{m}$. Split ratio 50:1; carrier gas $\mathrm{He}$ at a flow rate of $1.0 \mathrm{ml} / \mathrm{min}$. Temperature was programmed from $60^{\circ} \mathrm{C}$ to $180^{\circ} \mathrm{C}$ at the rate of $2.5^{\circ} \mathrm{C} / \mathrm{m}$ and then at the rate of $5{ }^{\circ} \mathrm{C}$ at $230^{\circ} \mathrm{C}$. Injection temperature was $200^{\circ} \mathrm{C}$. For GC-MS 5975C VLMSD with triple axis detector, Agilent technologies was used.

The identification of the components was based on comparison of their mass spectra with those of the NIST mass spectral library. Compounds which showed more than 90\% similarity was only considered.

\section{RESULTS AND DISCUSSION}

The genus Aristolochia is generally not treated as an important essential oil yielding plant. But being medicinal, the essential oil composition of the plant has been studied and tested for various activities [10-12]. 
Table 1: The overall oil composition of the stem and leaf oil of Aristolochia krisagathra in pre-monsoon, monsoon and post-monsoon periods

\begin{tabular}{|c|c|c|c|c|c|c|c|}
\hline \multirow[t]{3}{*}{ Name of compounds } & \multicolumn{6}{|c|}{ Percentage composition } & \multirow[t]{3}{*}{ Class of compound } \\
\hline & \multicolumn{3}{|c|}{ Stem } & \multicolumn{3}{|c|}{ Leaves } & \\
\hline & $\begin{array}{l}\text { Post- } \\
\text { monsoon }\end{array}$ & $\begin{array}{l}\text { Pre- } \\
\text { monsoon }\end{array}$ & Monsoon & Post-monsoon & Pre-monsoon & Monsoon & \\
\hline beta-elemene & 0.405 & - & - & 0.248 & - & - & $\mathrm{SH}$ \\
\hline alpha-gurjunene & - & - & 0.12 & 0.113 & - & - & $\mathrm{SH}$ \\
\hline caryophyllene & 0.29 & 0.282 & 0.738 & 2.731 & 5.126 & 0.78 & $\mathrm{SH}$ \\
\hline alloaromadendrene & 14.512 & 25.872 & 2.843 & 1.05 & - & 0.723 & SH \\
\hline $\begin{array}{l}\text { 2-pentadecanone } 6,10,14 \text { - } \\
\text { trimethyl }\end{array}$ & - & - & - & 3.033 & 3.312 & 0.454 & $\mathrm{CDC}$ \\
\hline beta-selinene & 2.544 & 2.018 & - & 3.084 & 2.312 & 0.537 & $\mathrm{SH}$ \\
\hline bicyclogermacrene & - & - & - & 2.028 & 4.462 & - & SH \\
\hline delta-cadinene & 0.36 & - & 6.065 & 7.244 & 5.021 & 5.425 & SH \\
\hline spathulenol & 0.549 & - & 7.1 & 6.333 & 5.845 & - & OS \\
\hline caryophyllene oxide & - & - & - & - & 3.634 & - & OS \\
\hline hexadecanoic acid, methyl ester & - & - & - & 0.22 & - & - & FAD \\
\hline n-hexadecanoic acid & - & - & 0.255 & 4.563 & 1.555 & 5.312 & FAD \\
\hline phytol & - & - & - & - & 6.388 & 2.026 & Diterpene \\
\hline alpha-caryophyllene & - & - & 0.219 & 2.537 & 3.928 & 0.953 & $\mathrm{SH}$ \\
\hline beta-maaliene & - & 9.053 & - & - & - & 1.641 & SH \\
\hline alpha-guaiene & - & - & - & - & 0.695 & - & SH \\
\hline isolongifolene, 9,10-dehydro & - & - & - & 0.118 & - & 0.332 & $\mathrm{SH}$ \\
\hline gama-cadinene & - & - & 1.641 & 2.319 & - & 1.17 & $\mathrm{SH}$ \\
\hline nerolidol & - & - & - & 0.602 & 0.608 & 1.659 & OS \\
\hline valencen & - & - & - & 0.184 & - & - & $\mathrm{SH}$ \\
\hline 9-octadecenoic acid & - & - & - & - & 1.092 & - & FAD \\
\hline copaene & 0.455 & - & 3.663 & 10.881 & 10.687 & 4.141 & $\mathrm{SH}$ \\
\hline isocaryophyllene & - & - & - & 3.72 & 7.233 & 1.734 & SH \\
\hline alpha-muurolene & - & - & 0.932 & 0.951 & 0.51 & - & $\mathrm{SH}$ \\
\hline alpha-farnesene & - & - & - & 0.576 & 1.131 & - & $\mathrm{SH}$ \\
\hline gama-gurjunene & - & - & 0.225 & - & - & 0.527 & SH \\
\hline alpha-cadinene & - & - & - & 0.245 & - & 0.267 & $\mathrm{SH}$ \\
\hline 1R-alpha-pinene & - & - & - & 0.608 & - & 0.323 & MH \\
\hline beta-pinene & - & 4.516 & - & 0.123 & - & - & $\mathrm{MH}$ \\
\hline D-limonene & 0.393 & - & - & 0.207 & - & - & MH \\
\hline linalool & - & - & - & 0.295 & 0.599 & - & $\mathrm{OM}$ \\
\hline beta-cadinene & - & - & - & 0.5 & - & - & $\mathrm{SH}$ \\
\hline delta-heptadecene & - & - & - & 0.401 & - & - & $\mathrm{HC}$ \\
\hline $\begin{array}{l}\text { 1H-indene } 1 \text {-ethylidene } \\
\text { octahydro-7a-methyl-cis }\end{array}$ & - & - & - & 0.416 & - & - & $\mathrm{HC}$ \\
\hline $\begin{array}{l}1 \mathrm{R}, 4 \mathrm{~S}, 7 \mathrm{~S}, 11 \mathrm{R}-2,2,4,8- \\
\text { tetramethyltricyclo } \\
{[5.3 .1 .0(4,11)] \text { undec-8-ene }}\end{array}$ & - & - & - & 0.136 & - & - & $\mathrm{HC}$ \\
\hline 1,5-cyclododecadiene (Z,Z) & - & - & - & 0.267 & - & - & $\mathrm{HC}$ \\
\hline isophytol & - & - & - & 0.31 & - & - & Diterpene \\
\hline $\begin{array}{l}\text { 9-octadecenoic acid (Z)-methyl } \\
\text { ester }\end{array}$ & - & - & - & 0.205 & 0.215 & 1.756 & FAD \\
\hline 9,17-octadecadienal (Z) & - & - & - & 0.966 & - & - & FAD \\
\hline$(+)-4$-carene & - & - & - & - & 0.718 & - & MH \\
\hline $\begin{array}{l}\text { bicyclo[4.4.0]dec-1-ene, } 2 \\
\text { isopropyl-5-methyl-9-methylene }\end{array}$ & - & - & - & - & 1.845 & 3.467 & $\mathrm{SH}$ \\
\hline alpha-cadinol & - & - & - & - & 1.934 & - & $\mathrm{SH}$ \\
\hline active amyl hexanoate & - & - & - & - & - & 0.217 & FAD \\
\hline levo-bornyl acetate & - & - & - & - & - & 0.883 & $\mathrm{OM}$ \\
\hline beta-bisabolene & - & - & - & - & - & 0.489 & $\mathrm{SH}$ \\
\hline 6,7 dimethyl tetralin & - & & - & 0.372 & - & - & $\mathrm{HC}$ \\
\hline gama-muurolene & - & - & & - & - & 1.981 & $\mathrm{SH}$ \\
\hline alpha-elemene & - & - & - & - & - & 1.442 & $\mathrm{SH}$ \\
\hline $\begin{array}{l}\text { (7R, 8S)-cis-anti-cis-7,8- } \\
\text { epoxytricneyclo[7.3.0.0(2,6)]dodec }\end{array}$ & - & - & - & - & - & 0.215 & $\mathrm{HC}$ \\
\hline $\begin{array}{l}\text { naphthalene, } 1,2,4 a, 5,6,8 a- \\
\text { hexahydro-4,7-dimethyl-1-(1- } \\
\text { methylethyl) }\end{array}$ & - & - & - & - & - & 0.809 & $\mathrm{SH}$ \\
\hline 9,12 -octadecadienoic acid $(\mathrm{Z}, \mathrm{Z})$ & & - & - & - & - & 0.383 & FAD \\
\hline germacrene D & - & - & 0.41 & & & & SH \\
\hline alpha-cubebene & - & - & 0.467 & & & & $\mathrm{SH}$ \\
\hline cyperene & 0.22 & - & - & & & & $\mathrm{SH}$ \\
\hline cadine 1,4-diene & - & - & 0.356 & 0.259 & 0.796 & 0.949 & SH \\
\hline trans-beta-ionone & & - & - & 0.95 & 0.266 & - & $\mathrm{CDC}$ \\
\hline dodecanoic acid & & - & - & 0.316 & - & 0.31 & FAD \\
\hline borneol & - & - & - & 0.139 & 0.219 & - & $\mathrm{OM}$ \\
\hline
\end{tabular}




\begin{tabular}{|c|c|c|c|c|c|c|c|}
\hline \multirow[t]{3}{*}{ Name of compounds } & \multicolumn{7}{|c|}{ Percentage composition } \\
\hline & \multicolumn{3}{|c|}{ Stem } & \multicolumn{3}{|c|}{ Leaves } & \multirow[t]{2}{*}{ Class of compound } \\
\hline & $\begin{array}{l}\text { Post- } \\
\text { monsoon }\end{array}$ & $\begin{array}{l}\text { Pre- } \\
\text { monsoon }\end{array}$ & Monsoon & Post-monsoon & Pre-monsoon & Monsoon & \\
\hline alpha-terpineol & - & - & - & 0.24 & 0.252 & 0.26 & $\mathrm{OM}$ \\
\hline$(-)$-myrtenol & 7.374 & 1.842 & - & 0.298 & - & - & $\mathrm{OM}$ \\
\hline tau-cadinol & - & - & 1.552 & 2.24 & - & 3.536 & SH \\
\hline tetradecanoic acid & - & - & - & 0.326 & - & 0.308 & FAD \\
\hline bornyl acetate & - & 0.972 & - & 0.153 & 0.873 & 0.513 & $\mathrm{OM}$ \\
\hline alpha-terpinyl isovalerate & - & - & - & 0.784 & - & - & $\mathrm{OM}$ \\
\hline beta-ionone & - & - & - & 0.264 & - & 0.427 & $\mathrm{CDC}$ \\
\hline Total percentage & 76.747 & 61.393 & 33.184 & 63.555 & 71.256 & 45.949 & \\
\hline Sesquiterpene hydrocarbons & 28.726 & 37.225 & 24.235 & 41.028 & 45.68 & 30.903 & \\
\hline Oxygenated sesquiterpenes & 0.549 & - & 7.1 & 6.935 & 10.087 & 1.659 & \\
\hline Monoterpene hydrocarbons & 18.461 & 17.728 & - & 0.938 & 0.718 & 0.323 & \\
\hline Oxygenated monoterpenes & 26.387 & 6.107 & 0.613 & 1.909 & 1.943 & 1.656 & \\
\hline Diterpenes & - & - & - & 0.31 & 6.388 & 2.026 & \\
\hline Hydrocarbons & - & - & 0.113 & 1.592 & - & 0.215 & \\
\hline Carotenoid derived compound & - & - & - & 4.247 & 3.578 & 0.881 & \\
\hline Fatty acid derivative & 1.312 & 0.333 & 0.96 & 6.596 & 2.862 & 8.286 & \\
\hline Benzotriazine & - & - & 0.163 & & & & \\
\hline
\end{tabular}

SH: Sesquiterpene hydrocarbons, OS: Oxygenated sesquiterpenes, MH: Monoterpene hydrocarbons, OM: Oxygenated monoterpenes, HC: Hydrocarbons, CDC: Carotenoid derived compound, FAD: Fatty acid derivative

Leaf and stem oil of $A$. krisagathra exhibited different colors and the oil yield from stem were higher than leaves. Different colors of oil in different developmental stages have been reported [13], but seasons were not found to influence oil color. Stable color of oil was observed throughout. The oil yield did not show significant variation with seasons in contrary to the reports by many $[14,15]$. Yield was partly described to be due to the structures associated with secretion; internal secretory structures maintaining a stable yield to external structures [16]. Hence the stable yield of oil with seasons in the present study could be attributed to localization of oil within individual cells. The number of volatiles identified from the leaf oil in different seasons was in the order post-monsoon $>$ monsoon $>$ pre-monsoon. This high number of volatiles in post-monsoon could be attributed to the physiological changes as it corresponds to the flowering period of the plant. However, in the stem oil the number of identified volatiles in the post-monsoon and monsoon was 26 and higher than in the pre-monsoon.
The leaf oil was dominated by copaene in pre-monsoon $(10.687 \%)$ and post-monsoon $(10.887 \%)$ period, whereas delta-cadinene $(5.425 \%)$ was the major compound in the monsoon. GC-MS chromatograms of the leaf oils are given (fig. 1-3). Delta-cadinene was reported as the major compound in the leaf oil [8]. Sesquiterpene hydrocarbons formed the major group in all the seasons. Oxygenated sesquiterpenes represented only a minor percentage. Monoterpene hydrocarbons and oxygenated monoterpenes were present in all seasons in minor quantities. The compounds commonly present in all the seasons in A. krisagathra leaves were caryophyllene, alpha-caryophyllene, beta-selinene, 2pentadecanone 6, 10, 14-trimethyl, n-hexadecanoic acid, deltacadinene, copaene, nerolidol, isocaryophyllene, alpha-terpineol,, bornyl acetate, cadine 1,4-diene and 9-octadecenoic acid (Z)-methyl ester (table 1).

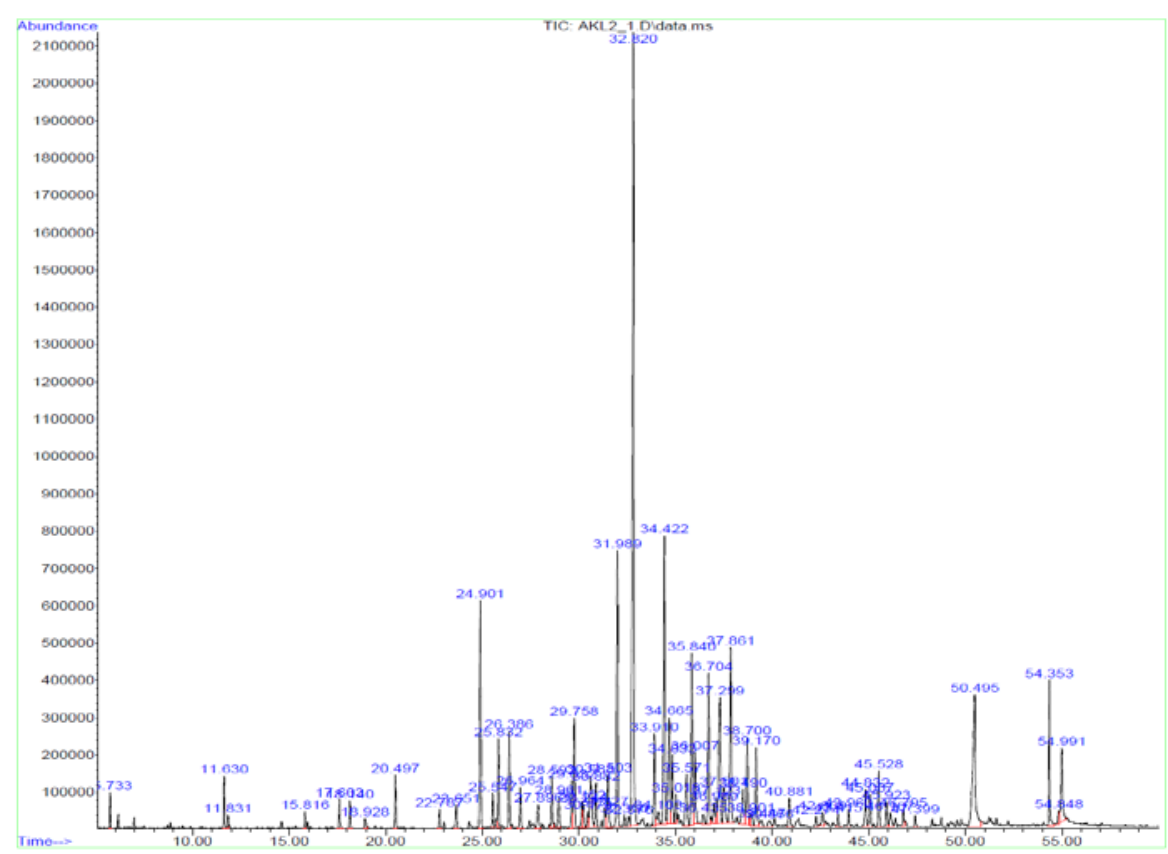

Fig. 1: GC-MS chromatogram of $A$. krisagathra leaves in the pre-monsoon period 


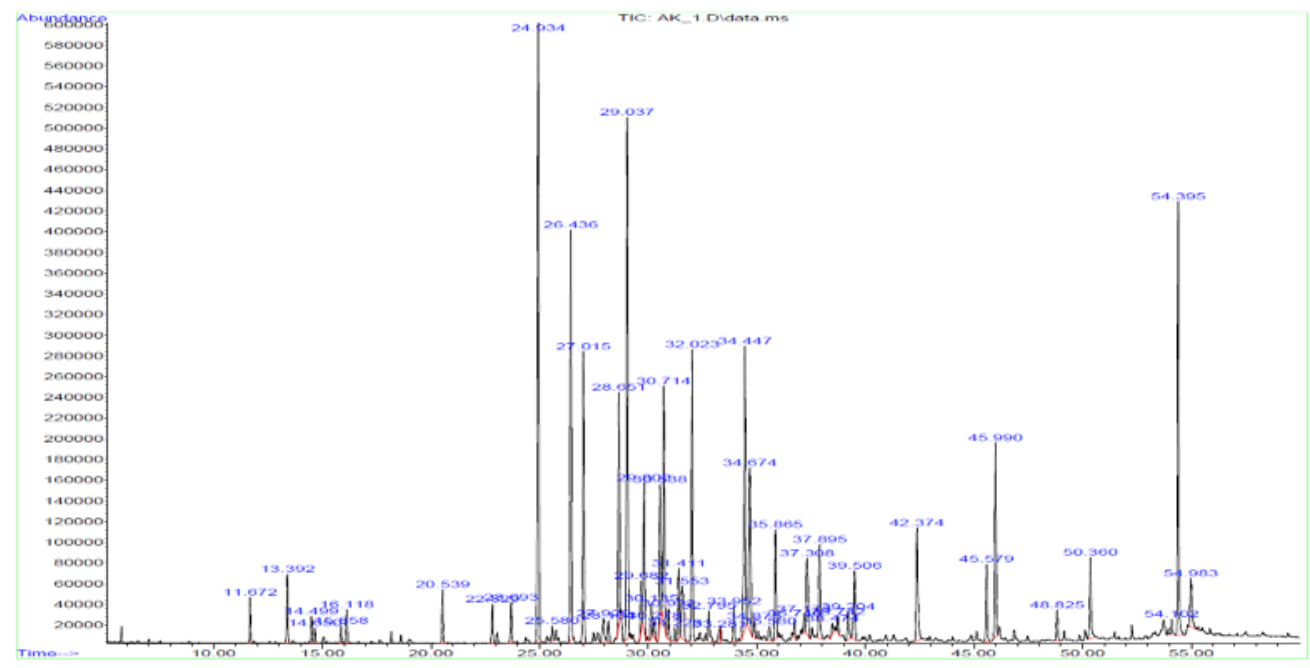

Fig. 2: GC-MS chromatogram of A. krisagathra leaves in the monsoon period

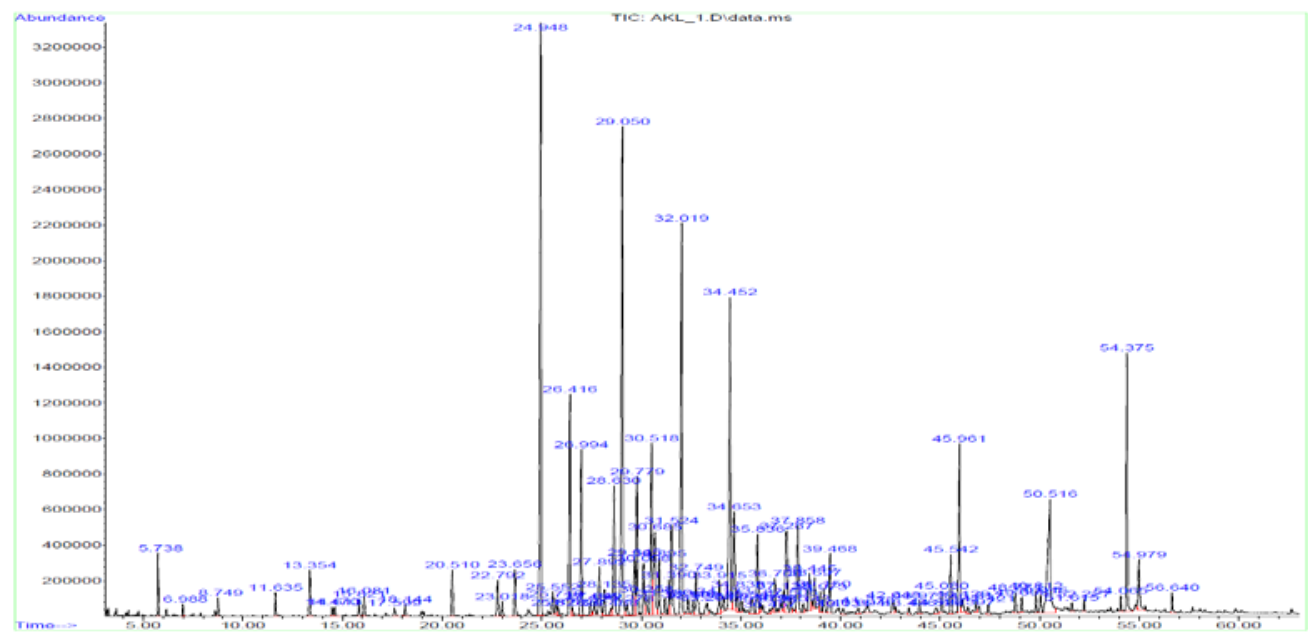

Fig. 3: GC-MS chromatogram of $A$. krisagathra leaves in the post-monsoon period

A. krisagathra stem oil showed alloaromadendrene as the major compound in the pre-(25.872\%) and post-monsoon $(14.512 \%)$ period and spathulenol (7.1\%) in monsoon period (table 1). GC-MS chromatograms of the stem oils are given (fig. 4-6). Spathulenol was the major compound in the stem oil of A. krisagathra in an earlier study [8]. Only two common compounds, caryophyllene, and alloaromadendrene, were present in the stem oil in all three seasons. Caryophyllene was the only compound present commonly in all the three seasons in both the stem and leaf oils of $A$. krisagathra (table 1).

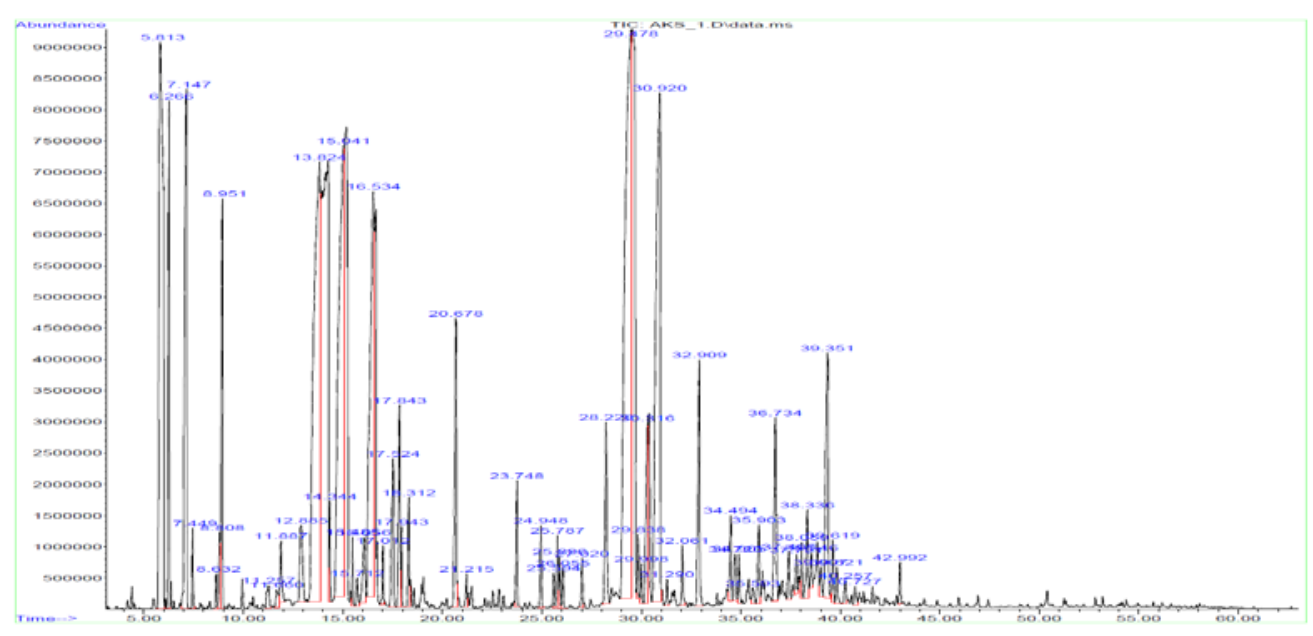

Fig. 4: GC-MS chromatogram of A. krisagathra stem in the pre-monsoon period 


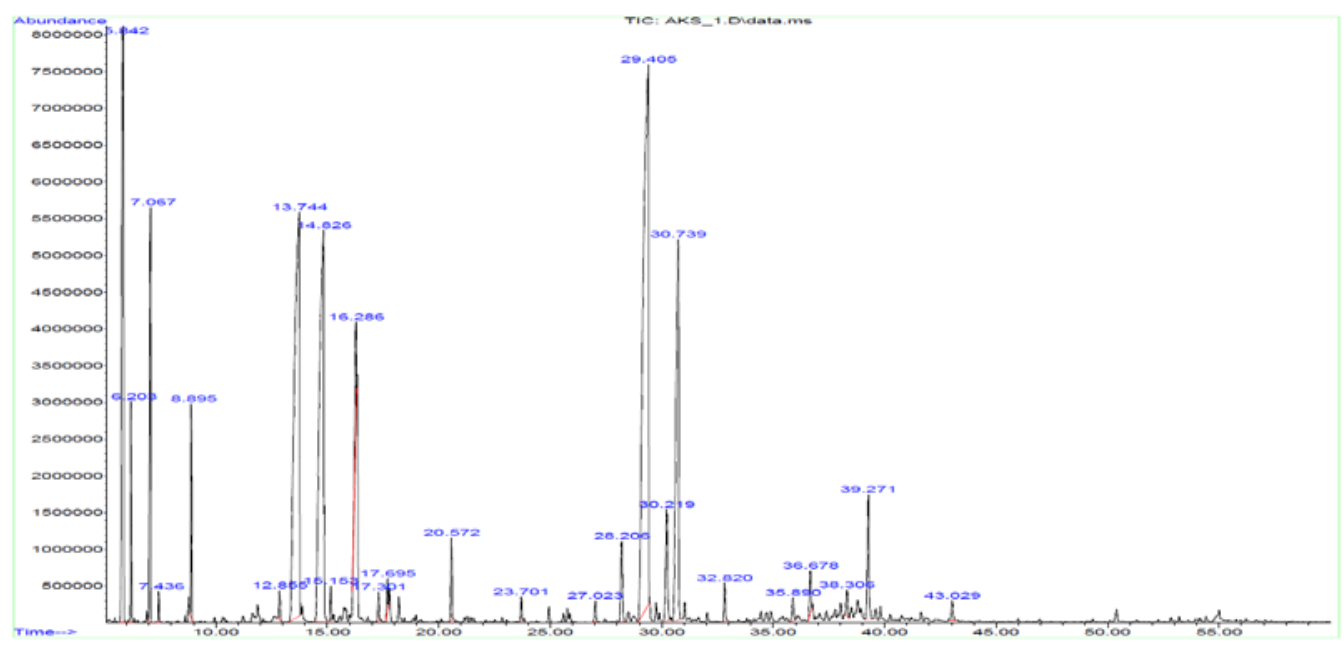

Fig. 5: GC-MS chromatogram of $A$. krisagathra stem in the monsoon period

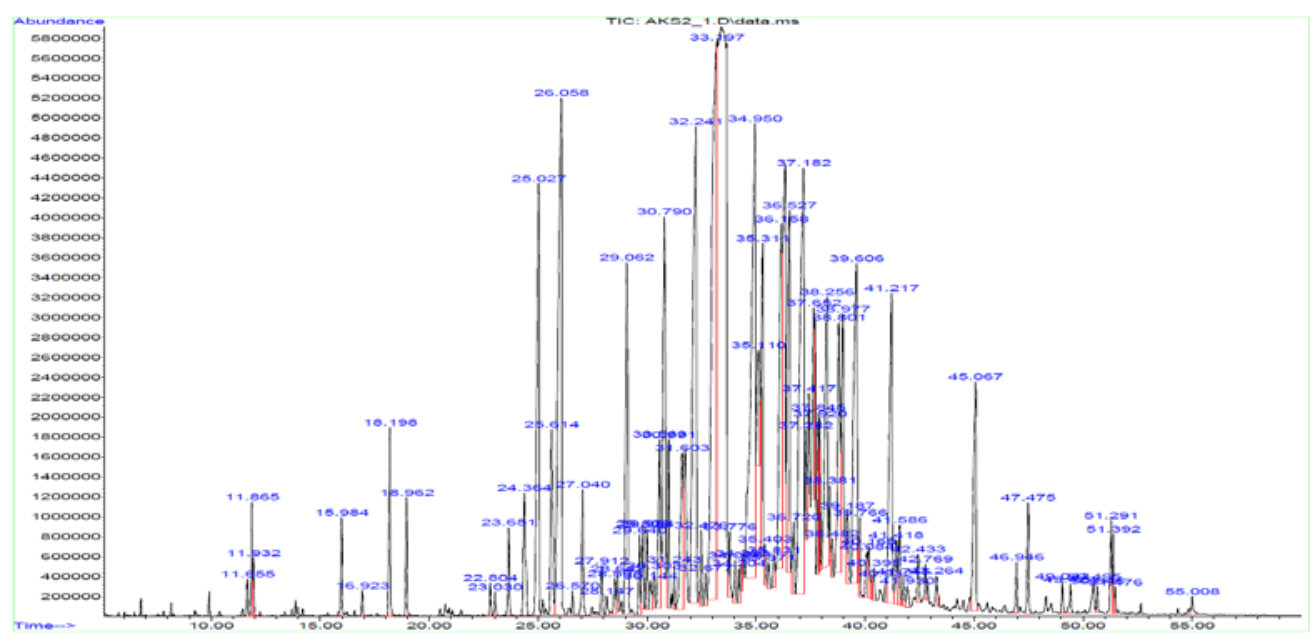

Fig. 6: GC-MS chromatogram of $A$. krisagathra stem in the post-monsoon period

Sesquiterpenes were the dominant class in the leaf oils in all the seasons and in the pre-monsoon and monsoon period in the stem oil. However, monoterpenes dominated in the stem oil in the postmonsoon period. Sesquiterpenes were reported to be the dominant group in leaf and stem oil of $A$. gibertii and A. triangularis $[17,18]$. Varying nature of dominant compounds with seasons was evident; the pre-monsoon and post-monsoon periods maintained stability in the major compound. The major compound varied in the monsoon period.

Thus, on considering the oil composition with respect to the factors such as seasons and plant parts, they were found to influence the quality of the oil. The accumulation of oil in different seasons and organs did not follow any regular pattern or trend. These variations may be the result of expression of different genes at different developmental stages of the plant and further by the environmental factors arising from seasonal variations [19].

\section{CONCLUSION}

Only less than $50 \%$ of compounds have been identified in the monsoon period. A. krisagathra, being endemic and medicinal with fewer studies on the phytochemistry, can turn out to be a potential plant harboring useful metabolites. Further studies and analyses on this plant are essential from the phytochemical aspect. Moreover, variation on oil composition with seasons has to be looked upon with great significance especially since $A$. krisagathra is medicinal and the essential oil has many activities. The study thereby indicates the importance of seasons in collecting medicinal plants.

\section{ACKNOWLEDGEMENT}

The author is grateful to Kerala State Council for Science, Technology and Environment for the Research Fellowship.

\section{CONFLICT OF INTERESTS}

Conflicts of interest declared none by all authors

\section{REFERENCES}

1. Neinhuis C, Wanke S, Hilu KW, Muller K, Borsch T. Phylogeny of aristolochiaceae based on parsimony, likelihood, and bayesian analyses of trnL-trnF sequences. Plant Syst Evol 2005;250:7-26.

2. Wanke S, Favio G, Christoph N. Systematics of pipevines: combining morphological and fast-evolving molecular characters to investigate the relationships within subfamily aristolochioideae (Aristolochiaceae). Int J Plant Sci 2006;167:1215-27.

3. Nayar TS, Rasiya BA, Mohanan N, Rajkumar G. Flowering plants of Kerala. A Handbook. Thiruvananthapuram: Tropical Botanic Garden and Research Institute; 2006

4. Ayyanar M, Ignacimuthu S. Medicinal plants used by the tribals of Tirunelveli hills, Tamil Nadu to treat poisonous bites and skin diseases. Indian J Traditional Knowledge 2005;4:229-36.

5. Murali S, Francis MS, Rashmi TR. Determination of aristolochic acid i concentration in the four species of Aristolochia using HPLC. Indo Am J Pharm Res 2014;4:2449-54.

6. Sharma Suman, Stuti Singh, James Bond, Apekshita Singh, Anjana Rustagi. Evaluation of antibacterial properties of 
essential oils from clove and eucalyptus. Asian J Pharm Clin Res 2014;7:291-4.

7. Cantoria MC. State of the art seminar series of biological sciences division. National Academy of Science and Technology, NAST Conference; 1985. p. 1-23.

8. Murali S, Francis MS, Rashmi TR. GC-MS analysis of stem and leaf oil of A. krisagathra sivarajan and pradeep-an endemic of Western Ghats, India. J Essent Oil-Bear Plants 2014;17:1130-6.

9. James AT, Martin AJ. Gas-liquid partition chromatography; the separation and micro-estimation of volatile fatty acids from formic acid to dodecanoic acid. Biochem J 1952;50:679-90.

10. Shafi PM, Rosamma MK, Kaiser J, Reddy PS. Antibacterial activity of the essential oil from Aristolochia indica. Fitoterapia 2002;73:439-41.

11. Wu TS, Amooru G, Da CRS, Ping CK. Terpenoids of Aristolochia and their biological activities. Nat Prod Rep 2004;21:594-624.

12. Yu JQ, Zhi XL, Xiao QC, Jia CL, Guo LZ. Composition, antimicrobial activity and cytotoxicity of essential oils from Aristolochia mollissima. Environ Toxicol Pharmacol 2007;23:162-7.

13. Figueiredo A, Cristina JG, Barroso MSP, Johannes JCS. The composition of the essential oils from leaves and flowers of Achillea millefolium L. ssp. millefolium. Flavour Fragrance J 1992; 7:219-22.

14. Gazim ZC, Ana CLA, Ana MCH, Claudia MR, Izalina AN, Gilberto $\mathrm{AF}$, et al. Seasonal variation, chemical composition, and analgesic and antimicrobial activities of the essential oil from leaves of Tetradenia riparia (Hochst.) codd in Southern Brazil. Molecules 2010;15:5509-24.

15. Santos GKN, Kamilla AD, Rosângela AB, Claudio AGC, Diana DL Norma BG, et al. Essential oils from Alpinia purpurata (Zingiberaceae): chemical composition, oviposition deterrence, larvicidal and antibacterial activity. Ind Crops Prod 2012;40:254-60.

16. Figueiredo AC, José GB, Luis GP, Johannes JCS. Factors affecting secondary metabolite production in plants: volatile components and essential oils. Flavour Fragrance J 2008;23:213-26.

17. Canela N, Esteban F, Nelson A, Roser V, Salvador C. Chemical composition of the essential oil of Aristolochia gibertii hooker from paraguay. J Essent Oil Res 2004;16:566-7.

18. Priestap HA, Bandoni AL, Neugebauer M, dRür G. Investigation of the essential oils from Aristolochia triangularis. J Essent Oil Res 1990;2:95-8.

19. Padalia RC, Ram SV, Amit C, Chandan SC. Seasonal variation in essential oil composition of Artemisia nilagirica var. septentrionalis from foot hills of western Himalaya. Rec Nat Prod 2014;8:281-5.

\section{How to cite this article}

- Soumya Murali, Rashmi TR, Francis MS. Influence of seasons and plant parts on the essential oil composition of the endemic species Aristolochia krisagathra Sivarajan and Pradeep. Int J Pharm Pharm Sci 2016;8(9):252-257. 